\title{
Communication
}

\section{Fe-substituted cobalt-phosphate polyoxometalates as enhanced oxygen evolution catalysts in acidic media}

\author{
Xin-Bao Han a, Dong-Xue Wang a, Eduardo Gracia-Espino c, Yu-Hui Luo d, Yuan-Zhi Tan a,*, \\ Dong-Fei Lu a , Yang-Guang Li b,\#, Thomas Wågberg c,\$, En-Bo Wang b, Lan-Sun Zheng a \\ a State Key Laboratory of Physical Chemistry of Solid Surfaces, and Department of Chemistry, College of Chemistry and Chemical Engineering, Xiamen \\ University, Xiamen 361005, Fujian, China \\ b Key Laboratory of Polyoxometalate Science of the Ministry of Education, Faculty of Chemistry, Northeast Normal University, Changchun 130024, Jilin, \\ China \\ c Department of Physics, Umeå University, Umeå 90187, Sweden \\ d Department of Chemical Engineering, Huaihai Institute of Technology, Lianyungang 222000, Jiangsu, China
}

\section{A R T I C L E I N F O}

\section{Article history:}

Received 30 July 2019

Accepted 28 August 2019

Published 5 May 2020

\section{Keywords:}

Colbalt-phosphate

Polyoxometalate

Oxygen evolution reaction

Isostructural substitution

\begin{abstract}
A B S T R A C T
All-inorganic and earth-abundant bi-/trimetallic hydr(oxy)oxides are widely used as oxygen evolution electrocatalysts owing to their remarkable performance. However, their atomically precise structures remain undefined, complicating their optimization and limiting the understanding of their enhanced performance. Here, the underlying structure-property correlation is explored by using a well-defined cobalt-phosphate polyoxometalate cluster $\left[\left\{\mathrm{Co}_{4}(\mathrm{OH})_{3}\left(\mathrm{PO}_{4}\right)\right\}_{4}\left(\mathrm{SiW}_{9} \mathrm{O}_{34}\right)_{4}\right]^{32-}(\mathbf{1})$, which may serve as a molecular model of multimetal hydr(oxy)oxides. The catalytic activity is enhanced upon replacing Co by Fe in $\mathbf{1}$, resulting in a reduced overpotential (385 mV) for oxygen evolution (by $66 \mathrm{mV}$ ) compared to that of the parent $\mathbf{1}$ at $10 \mathrm{~mA} \mathrm{~cm}-2$ in an acidic medium; this overpotential is comparable to that for the $\mathrm{IrO}_{2}$ catalyst. These abundant-metal-based polyoxometalates exhibit high stability, with no evidence of degradation even after $24 \mathrm{~h}$ of operation.
\end{abstract}

(c) 2020, Dalian Institute of Chemical Physics, Chinese Academy of Sciences. Published by Elsevier B.V. All rights reserved.
The oxygen evolution reaction (OER) is the key half-reaction for many renewable energy conversion and storage technologies, including electrocatalytic water splitting and $\mathrm{CO}_{2}$ reduction. The sluggish kinetics of the OER have long been the bottleneck hindering the widespread use of such technologies [1-3]. Ru- and Ir-based materials are the state-of-the-art OER catalysts, but they suffer from disadvantages such as scarcity, high cost, and low intrinsic activity [4,5]. In the past decades, the development of all-inorganic and earth-abundant bi-/tri-metallic hydr(oxy)oxides as OER catalysts for alkaline media (metal oxides [6,7], hydr(oxy)oxides [8,9], cobalt-phosphate composites $[10,11]$, etc.) has been successful, and these materials exhibit excellent activity. Unfortunately, the lack of in-depth knowledge about the relationship between their atomically precise structures and the origin of their enhanced performance has hindered further design of active, stable, and cost-effective OER electrocatalysts. Metal-organic frameworks (MOFs), which have a well-defined atomic architecture, could per se be used to reveal the structure-property relationship at the molecular level $[12,13]$. However, MOFs are

\footnotetext{
* Corresponding author. E-mail: yuanzhi_tan@xmu.edu.cn

\# Corresponding author. E-mail: liyg658@nenu.edu.cn

\$Corresponding author. E-mail: thomas.wagberg@physics.umu.se

This work was supported by the National Natural Science Foundation of China $(21771155,21721001)$ and the Ministry of Science and Technology of China (2014CB845603, 2017YFA0204902). T. W. acknowledges support from Vetenskapsrådet (2017-04862) and Energimyndigheten (45419-1). DOI: 10.1016/S1872-2067(20)63538-0 | http://www.sciencedirect.com/science/journal/18722067| Chin. J. Catal., Vol. 41, No. 5, May 2020
} 
composed of metal ions (or clusters) and organic linkers, and therefore, are less suitable as model systems for hydr(oxy)oxides.

Polyoxometalates (POMs) constitute a class of well-defined metal-oxo clusters. They feature well-defined and unique structural motifs, and can be seen as an intermediate between molecular complexes and extended oxides [14]. In addition, all-inorganic, oxidatively-resistant, and earth-abundant POMs with excellent OER activity have been produced [15-26]. Therefore, POMs are ideal candidates for a molecular model of bi-/tri-metallic hydr(oxy)oxides to explore the origin of the improved catalytic activity in the OER and to gain a clearer insight into the structure-property correlation.

For the OER, acidic media are preferred because of numerous advantages over alkaline media, such as high energy efficiency, low Ohmic losses, and easy product separation or carbonation [23,27]. Unfortunately, earth-abundant OER electrocatalysts are unstable toward dissolution in acidic media and are typically inferior to noble-metal-based catalysts $[1,23,28]$. Developing highly active and stable earth-abundant OER catalysts in acidic media remains a great challenge in this area. Herein we show that by substitution of a parent POM cluster, $\left\{\mathrm{Co}_{4}(\mathrm{OH})_{3}\left(\mathrm{PO}_{4}\right)_{4}\left(\mathrm{SiW}_{9} \mathrm{O}_{34}\right)_{4}\right]^{32-}(\mathbf{1})$, with $\mathrm{Fe}$ into two isostructurally analogous $\quad \mathrm{POM}$ clusters $\left[\left\{\mathrm{Fe}_{2} \mathrm{Co}_{2}(\mathrm{OH})_{3} \mathrm{PO}_{4}\right\}_{4}\left(\mathrm{SiW}_{9} \mathrm{O}_{34}\right)_{4}\right]^{24-} \quad$ (2) and $\left[\left\{\mathrm{FeCo}_{3}(\mathrm{OH})_{3} \mathrm{PO}_{4}\right\}_{4}\left(\mathrm{SiW}_{9} \mathrm{O}_{34}\right)_{4}\right]^{28-}(3)$, we can achieve significantly enhanced OER performance. The insoluble barium salt of $3(\mathrm{Ba}[3])$ is the best catalyst, with an overpotential of $385 \mathrm{mV}$ at $10 \mathrm{~mA} \mathrm{~cm}^{-2}$ in $0.5 \mathrm{M} \mathrm{H}_{2} \mathrm{SO}_{4}$; this overpotential is $66 \mathrm{mV}$ lower than that of the barium salt of $\mathbf{1}(\mathrm{Ba}[\mathbf{1}])$ and comparable to that of the commercial $\mathrm{IrO}_{2}$ catalyst under similar conditions (393 mV). These catalysts exhibit negligible activity decay and retain their structural integrity even after 2000 cyclic voltammetry (CV) cycles and $24 \mathrm{~h}$ of long-term electrolysis.

The synthetic routes to $\mathbf{1}, \mathbf{2}$, and $\mathbf{3}$ and the structures of these compounds are shown in Fig. 1. Single-crystal X-ray diffraction (SCXRD) analysis confirms their isostructural characteristics [18,29]. The water-insoluble barium salts of

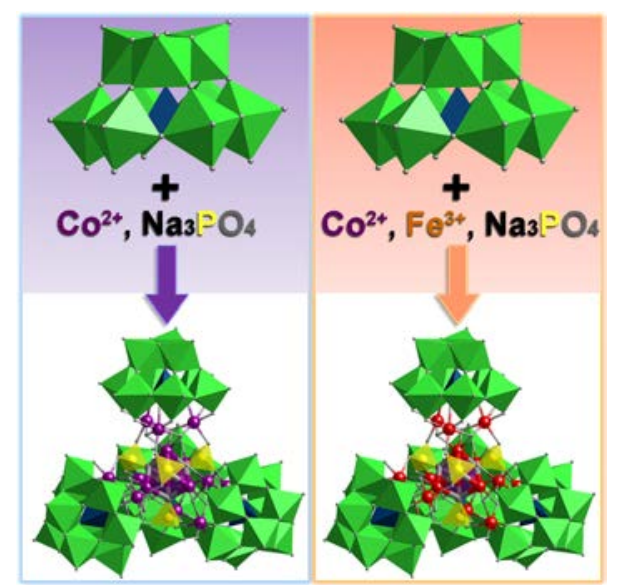

Fig. 1. Synthetic routes to $\left[\left\{\mathrm{Co}_{X} \mathrm{Fe}_{4-x}(\mathrm{OH})_{3}\left(\mathrm{PO}_{4}\right)\right\}_{4}\left(\mathrm{SiW}_{9} \mathrm{O}_{34}\right)_{4}\right]^{n-}(X=4,2$, or $1 ; n=32,24$, or 28). Polyhedral and ball-and-stick representations of the structure of $\left[\left\{\mathrm{Co}_{x} \mathrm{Fe}_{4-x}(\mathrm{OH})_{3}\left(\mathrm{PO}_{4}\right)\right\}_{4}\left(\mathrm{SiW}_{9} \mathrm{O}_{34}\right)_{4}\right]^{n-}$. WO hedra; $\mathrm{SiO}_{4}$, blue tetrahedra; $\mathrm{PO}_{4}$, yellow tetrahedra; O, gray spheres; Co violet spheres; $\mathrm{P}$, yellow spheres.
$\mathrm{Ba}_{16}\left[\left\{\mathrm{Co}_{4}(\mathrm{OH})_{3}\left(\mathrm{PO}_{4}\right)\right\}_{4}\left(\mathrm{SiW}_{9} \mathrm{O}_{34}\right)_{4}\right] \quad(\mathrm{Ba}[\mathbf{1}]), \mathrm{Ba}_{12}\left[\left\{\mathrm{Fe}_{2} \mathrm{Co}_{2}(\mathrm{OH})_{3}\right.\right.$ $\left.\left.\mathrm{PO}_{4}\right\}_{4}\left(\mathrm{SiW}_{9} \mathrm{O}_{34}\right)_{4}\right] \quad(\mathrm{Ba}[2]), \quad$ and $\mathrm{Ba}_{14}\left[\left\{\mathrm{FeCO}_{3}(\mathrm{OH})_{3} \mathrm{PO}_{4}\right\}_{4}\right.$ $\left.\left(\mathrm{SiW}_{9} \mathrm{O}_{34}\right)_{4}\right](\mathrm{Ba}[3])$ were prepared by simple metathesis of the corresponding countercations $\mathrm{Na}^{+}$or $\mathrm{K}^{+}$into $\mathrm{Ba}^{2+}$. The FT-IR bands provide a reliable fingerprint for the POM structures [23,30,31]. The presence of $\mathbf{1}$ in $\mathrm{Ba}[\mathbf{1}], \mathbf{2}$ in $\mathrm{Ba}[\mathbf{2}]$, and $\mathbf{3}$ in $\mathrm{Ba}[3]$ was confirmed by FT-IR spectroscopy (Fig. S1 in SI). Besides, the corresponding signature FT-IR spectra of Fe-substituted $\mathrm{Ba}[2]$ and $\mathrm{Ba}[3]$ were consistent with that of the parent $\mathrm{Ba}[\mathbf{1}]$, due to the isostructural nature of $\mathbf{1}, \mathbf{2}$, and $\mathbf{3}$.

The OER activities of $\mathrm{Ba}[\mathbf{1}], \mathrm{Ba}[2]$, and $\mathrm{Ba}[\mathbf{3}]$ were measured using a typical three-electrode system in $\mathrm{O}_{2}$-saturated $0.5 \mathrm{~mol}$ $\mathrm{L}^{-1} \mathrm{H}_{2} \mathrm{SO}_{4}$ solution at $25{ }^{\circ} \mathrm{C}$. Linear sweep voltammetry (LSV) experiments were performed at a scan rate of $5 \mathrm{mV} \mathrm{s}^{-1}$ after the system reached equilibrium. The electrodes were prepared by mixing $\mathrm{Ba}[1], \mathrm{Ba}[2]$, or $\mathrm{Ba}[3]$ with commercial carbon paste oil (CPO) at $40 \%$ content by weight [23]. As shown in Figure 2a, both $\mathrm{Ba}[2] / \mathrm{CPO}$ and $\mathrm{Ba}[3] / \mathrm{CPO}$ electrodes showed significantly enhanced electrocatalytic activity as compared with the Fe-free $\mathrm{Ba}[\mathbf{1}] / \mathrm{CPO}$ electrode. $\mathrm{Ba}[2] / \mathrm{CPO}$ showed an overpotential of $406 \mathrm{mV}$ at $10 \mathrm{~mA} \mathrm{~cm}-2$ (Table 1), which was $45 \mathrm{mV}$ smaller than that of $\mathrm{Ba}[\mathbf{1}] / \mathrm{CPO}(451 \mathrm{mV})$. With a decrease in the Fe substitution ratio, the corresponding overpotential decreased to $385 \mathrm{mV}$ for $\mathrm{Ba}[3] / \mathrm{CPO}$ (66 $\mathrm{mV}$ smaller than that of $\mathrm{Ba}[\mathbf{1}] / \mathrm{CPO}$ ). Because of the isostructural nature of $\mathbf{1}, \mathbf{2}$, and 3, the enhanced OER catalysis was attributed solely to the Fe substitution, which gives us a well-defined model for substitution effects on the catalytic enhancement. It is also noteworthy that excess $\mathrm{Fe}$, as in the case of $\mathrm{Ba}[2]$, can lead to an increase in the OER overpotential. These results are consistent with those of previous studies using $\mathrm{W}_{23} \mathrm{Co}_{w} \mathrm{Fe}_{x} \mathrm{O}_{y}(\mathrm{OH})_{z}$ transition-metal clusters (TMCs) [29], where the lower Fe content favored low adsorption energies $\left(\Delta G_{\mathrm{O}}-\Delta G_{\mathrm{OH}}>1.6 \mathrm{eV}\right)$ for the OER intermediates, while a larger Fe content was associated with large adsorption energies $\left(\Delta G_{0}-\Delta G_{\mathrm{OH}}<1.6 \mathrm{eV}\right)$. In this case, an optimum catalyst would exhibit a free-energy difference $\left(\Delta G_{0}-\right.$ $\left.\Delta G_{\mathrm{OH}}\right)$ of around $1.6 \mathrm{eV}$, resulting in the well-known volcano-like behavior [32,33].

A modified electrode of $40 \% \mathrm{IrO}_{2} / \mathrm{CPO}$ was prepared for comparison, and its OER performance was examined under the same conditions. At $10 \mathrm{~mA} \mathrm{~cm}-2$, the $\mathrm{IrO}_{2} / \mathrm{CPO}$ electrode produced an overpotential of $393 \mathrm{mV}$ (Fig. $2 \mathrm{~b}$ and Table 1), which was $8 \mathrm{mV}$ higher than that of $\mathrm{Ba}[3] / \mathrm{CPO}$. In $1.0 \mathrm{M} \mathrm{H}_{2} \mathrm{SO}_{4}$, the

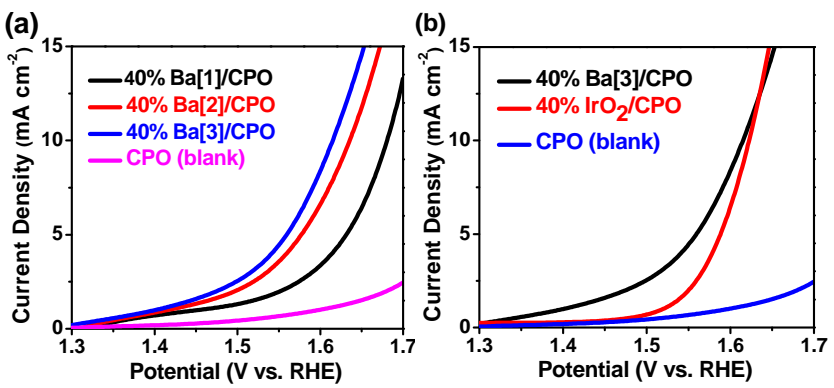

Fig. 2. (a) LSV curves of $\mathrm{Ba}[1] / \mathrm{CPO}, \mathrm{Ba}[2] / \mathrm{CPO}, \mathrm{Ba}[3] / \mathrm{CPO}$, and pure CPO electrodes in $0.5 \mathrm{~mol} \mathrm{~L}^{-1} \mathrm{H}_{2} \mathrm{SO}_{4}$, no iR correction. (b) LSV curves of $\mathrm{Ba}[3] / \mathrm{CPO}, \mathrm{IrO}_{2} / \mathrm{CPO}$, and pure $\mathrm{CPO}$ electrodes in $0.5 \mathrm{~mol} \mathrm{~L}^{-1} \mathrm{H}_{2} \mathrm{SO}_{4}$, no $i R$ correction. 
Table 1

Overpotential $(\eta)$ of different catalysts at $10 \mathrm{~mA} \mathrm{~cm}^{-2}$ in acidic electrolyte.

\begin{tabular}{lccc}
\hline Catalyst & Electrolyte & $\eta(\mathrm{mV})$ & Ref. \\
\hline $\mathrm{Ba}[1] / \mathrm{CPO}$ & $0.5 \mathrm{~mol} \mathrm{~L}^{-1} \mathrm{H}_{2} \mathrm{SO}_{4}$ & $451^{\mathrm{a}}$ & This work \\
$\mathrm{Ba}[2] / \mathrm{CPO}$ & $0.5 \mathrm{~mol} \mathrm{~L}^{-1} \mathrm{H}_{2} \mathrm{SO}_{4}$ & $406^{\mathrm{a}}$ & This work \\
$\mathrm{Ba}[3] / \mathrm{CPO}$ & $0.5 \mathrm{~mol} \mathrm{~L}^{-1} \mathrm{H}_{2} \mathrm{SO}_{4}$ & $385^{\mathrm{a}}$ & This work \\
$\mathrm{IrO}_{2} / \mathrm{CPO}$ & $0.5 \mathrm{~mol} \mathrm{~L}^{-1} \mathrm{H}_{2} \mathrm{SO}_{4}$ & $393^{\mathrm{a}}$ & This work \\
$\mathrm{Co}_{3} \mathrm{O}_{4} / \mathrm{FTO}$ & $0.5 \mathrm{~mol} \mathrm{~L}^{-1} \mathrm{H}_{2} \mathrm{SO}_{4}$ & $570^{\mathrm{b}}$ & {$[34]$} \\
$\gamma$ - $\mathrm{MnO}_{2} / \mathrm{FTO}$ & $1.0 \mathrm{~mol} \mathrm{~L}^{-1} \mathrm{H}_{2} \mathrm{SO}_{4}$ & $489 \pm 5^{\mathrm{b}}$ & {$[35]$} \\
$\mathrm{Ni}_{0.5} \mathrm{Mn} 0.5 \mathrm{Sb}{ }_{1.7} \mathrm{O}_{\mathrm{y}}$ & $1.0 \mathrm{~mol} \mathrm{~L}^{-1} \mathrm{H}_{2} \mathrm{SO}_{4}$ & $672 \pm 9^{\mathrm{b}}$ & {$[7]$} \\
$\mathrm{IrO}_{2} / \mathrm{FTO}$ & $0.5 \mathrm{~mol} \mathrm{~L}^{-1} \mathrm{H}_{2} \mathrm{SO}_{4}$ & $330^{\mathrm{b}}$ & {$[34]$} \\
$\mathrm{Ba}[\mathrm{Co}-\mathrm{POM}] / \mathrm{CP}$ & $1.0 \mathrm{~mol} \mathrm{~L}^{-1} \mathrm{H}_{2} \mathrm{SO}_{4}$ & $361^{\mathrm{b}}$ & {$[23]$} \\
$\mathrm{Ba}[3] / \mathrm{CPO}$ & $1.0 \mathrm{~mol} \mathrm{~L}^{-1} \mathrm{H}_{2} \mathrm{SO}_{4}$ & $398^{\mathrm{a}}$ & This work \\
\hline
\end{tabular}

a Overpotentials were obtained without $i R$ correction.

b Overpotentials were obtained with $i R$ correction.

$\mathrm{Ba}[3] / \mathrm{CPO}$ electrode generated an overpotential of $398 \mathrm{mV}$ at $10 \mathrm{~mA} \mathrm{~cm}^{-2}$ (Table 1 and Fig. S2 in SI), which is comparable to the remarkable example of the $\mathrm{Ba}[\mathrm{Co}-\mathrm{POM}]$ catalyst [23]. To the best of our knowledge, $\mathrm{Ba}[3]$ is also one of the best non-noble metal-based OER electrocatalysts in acidic media (Table 1).

To gain better insight into the superior performance of $\mathrm{Ba}[3] / \mathrm{CPO}$, we estimated the available active sites in the modified electrodes by evaluating the total amounts of Fe and Co, assuming that both are active during the OER. This approach imposes an upper limit on the available active sites. In comparison, the $\mathrm{IrO}_{2} / \mathrm{CPO}$ mixture contains almost 3.4 times more active sites than does the corresponding $\mathrm{Ba}[3] / \mathrm{CPO}$ mixture (Table S1 in SI). For comparison, a modified electrode of $12 \%$ $\mathrm{IrO}_{2} / \mathrm{CPO}$ with a similar mass of active sites as $40 \% \mathrm{Ba}[3] / \mathrm{CPO}$ was prepared, and its OER performance was examined under the same conditions. As shown in Table S1 and Fig. S3, 12\% $\mathrm{IrO}_{2} / \mathrm{CPO}$ exhibits an overpotential of $528 \mathrm{mV}$ at $10 \mathrm{~mA} \mathrm{~cm}-2$, which is greater than that of $\mathrm{Ba}[\mathbf{1}] / \mathrm{CPO}(385 \mathrm{mV}$ ) by $143 \mathrm{mV}$. These results suggest that $\mathrm{Ba}[3]$ may show better intrinsic activity than the state-of-the-art $\mathrm{IrO}_{2}$ at $10 \mathrm{~mA} \mathrm{~cm}^{-2}$ in acidic media, but its activity might be limited by other parameters such as electron transfer, as indicated by the magnitude of the Tafel slope. The Tafel slopes of all the catalysts are depicted in Fig. S4 in SI. Ba[1] (194 mV dec ${ }^{-1}$ ) and $\mathrm{Ba}$ [2] (189 $\mathrm{mV} \mathrm{dec}^{-1}$ ) exhibit a larger Tafel slope than does $\mathrm{Ba}[3]$, suggesting that the OER is kinetically favored on $\mathrm{Ba}$ [3] (181 $\mathrm{mV} \mathrm{dec}^{-1}$ ). Similar large Tafel slopes have been reported for other POM-based OER electrocatalysts [23-25], possibly due to the competition between a chemical step and an electron-transfer limiting step [23]. In the case of $\mathrm{IrO}_{2}$, a smaller Tafel slope was observed ( $96 \mathrm{mV} \mathrm{dec}^{-1}$ ).

The operational stability of the $\mathrm{Ba}[\mathbf{1}], \mathrm{Ba}[2]$, and $\mathrm{Ba}[3]$ catalysts was evaluated by a long-term cycling test in $0.5 \mathrm{M}$ aqueous $\mathrm{H}_{2} \mathrm{SO}_{4}$ solution. Satisfactorily, the LSV curves after $2000 \mathrm{CV}$ cycles practically overlapped with the original ones, displaying a very small change in overpotential $(<8 \mathrm{mV})$ at $10 \mathrm{~mA} \mathrm{~cm}-2$ (Fig. 3a and Figs. S5 and S6 in SI). Chronoamperometric response $(i-t)$ tests further showed that all the three catalysts maintained their activity for at least $24 \mathrm{~h}$ of electrolysis (Fig. $3 \mathrm{~b}$ and Figs. S7 and S8 in SI). In particular, the LSV curves of $\mathrm{Ba}[3] / \mathrm{CPO}$ showed only a minimal overpotential change $(<25$
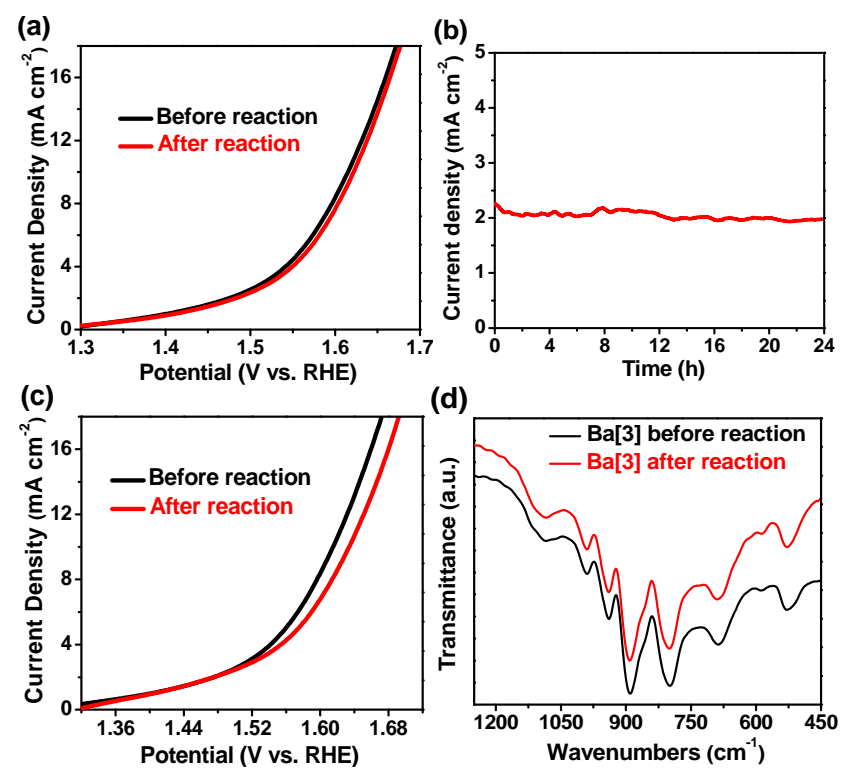

Fig. 3. (a) LSV curves of $\mathrm{Ba}[3] / \mathrm{CPO}$ electrode before and after $2000 \mathrm{CV}$ cycles. (b) Chronoamperometric response of $\mathrm{Ba}[3] / \mathrm{CPO}$ for $24 \mathrm{~h}$ at a constant applied potential of $1.48 \mathrm{~V}$ vs. RHE. (c) LSV curves of $\mathrm{Ba}[3] / \mathrm{CPO}$ electrode before and after $24 \mathrm{~h}$ of long-term electrolysis. (d) FT-IR spectra of $\mathrm{Ba}[3]$ before and after long-term operation.

mV, Fig. 3c) at $10 \mathrm{~mA} \mathrm{~cm}^{-2}$ after $24 \mathrm{~h}$ of electrolysis.

To evaluate the structural integrity under operation, the FT-IR spectra of the POM catalysts after the stability test were measured [21,22,36]. The FT-IR spectra of $\mathrm{Ba}[\mathbf{1}]$ (Fig. S9 in SI), $\mathrm{Ba}$ [2] (Fig. S10 in SI), and Ba[3] (Fig. 3d) after $2000 \mathrm{CV}$ cycles were largely identical to those of the as-synthesized catalysts. Inductively coupled plasma-mass spectrometry (ICP-MS) analysis was carried out to quantify the metal $(\mathrm{Ba}, \mathrm{Co}, \mathrm{Fe}$, or W) content in the $0.5 \mathrm{~mol} \mathrm{~L}^{-1} \mathrm{H}_{2} \mathrm{SO}_{4}$ mother liquor after $2000 \mathrm{CV}$ cycles. The ICP-MS data demonstrated that quite a few amount (around 2\%) of metal may leach out of the prepared catalysts (Table S2 in SI). These results collectively suggested the superior stability of these three bi-/trimetallic earth-abundant electrocatalysts.

In summary, the OER performance of an earth-abundant POM-based cobalt-phosphate cluster is largely improved by isostructural Fe substitution. The best catalyst $\mathrm{Ba}$ [3] exhibits an overpotential of $385 \mathrm{mV}$ at $10 \mathrm{~mA} \mathrm{~cm}^{-2}$ in $0.5 \mathrm{~mol} \mathrm{~L}^{-1} \mathrm{H}_{2} \mathrm{SO}_{4}$ solution, which is comparable to that observed for the $\mathrm{IrO}_{2}$ catalyst. Multiple experiments collectively confirmed the good operational stability of $\mathrm{Ba}[3]$. Our "in situ isostructural substitution" approach affords a synthetic route to well-defined multimetallic catalysts with enhanced performance. This also offers the ideal model for future experimental or theoretical work to study the structure-property correlation in detail, with the aim of developing more efficient molecular-based heterogeneous catalysts beyond OERs and understanding the related catalytic mechanisms.

Supporting Information. Electrocatalytic experiments, ICP-MS analysis and IR spectra. 


\section{References}

[1] C. C. L. McCrory, S. Jung, I. M. Ferrer, S. M. Chatman, J. C. Peters, T. F. Jaramillo, J. Am. Chem. Soc., 2015, 137, 4347-4357.

[2] B. M. Hunter, H. B. Gray, A. M. Müller, Chem. Rev., 2016, 116, 14120-14136.

[3] N.-T. Suen, S.-F. Hung, Q. Quan, N. Zhang, Y.-J. Xu, H. M. Chen, Chem. Soc. Rev., 2017, 46, 337-365.

[4] Y. Pi, Q. Shao, P. Wang, F. Lv, S. Guo, J. Guo, X. Huang, Angew. Chem. Int. Ed., 2017, 56, 4502-4506.

[5] I. A. Moreno-Hernandez, C. A. MacFarland, C. G. Read, K. M. Papadantonakis, B. S. Brunschwig, N. S. Lewis, Energy Environ. Sci, 2017, 10, 2103-2108.

[6] J. Suntivich, K. J. May, H. A. Gasteiger, J. B. Goodenough, Y. Shao-Horn, Science, 2011, 334, 1383-1385.

[7] R. D. L. Smith, M. S. Prévot, R. D. Fagan, Z. Z. Zhang, P. A. Sedach, M. K. J. Siu, S. Trudel, C. P. Berlinguette, Science, 2013, 340, 60-63.

[8] M. Gong, Y. Li, H. Wang, Y. Liang, J. Wu, J. Zhou, J. Wang, T. Regier, F. Wei, H. Dai, J. Am. Chem. Soc., 2013, 135, 8452-8455.

[9] B. Zhang, X. Zheng, O. Voznyy, R. Comin, M. Bajdich, M. García-Melchor, L. Han, J. Xu, M. Liu, L. Zheng, F. P. G. D. Arquer, C. T. Dinh, F. Fan, M. Yuan, E. Yassitepe, N. Chen, T. Regier, P. Liu, Y. Li, P. D. Luna, A. Janmohamed, H. L. Xin, H. Yang, A. Vojvodic, E. H. Sargent, Science, 2016, 352, 333-337.

[10] M. W. Kanan, D. G. Nocera, Science, 2008, 321, 1072-1075.

[11] K. Jin, J. Park, J. Lee, K. D. Yang, G. K. Pradhan, U. Sim, D. Jeong, H. L. Jang, S. Park, D. Kim, N.-E. Sung, S. H. Kim, S. Han, K. T. Nam, J. Am. Chem. Soc., 2014, 136, 7435-7443

[12] S. L. Zhao, Y. Wang, J. C. Dong, C.-T. He, H. J. Yin, P. F. An, K. Zhao, X. F. Zhang, C. Gao, L. J. Zhang, J. W. Lv, J. X. Wang, J. Q. Zhang, A. M. Khattak, N. A. Khan, Z. X. Wei, J. Zhang, S. Q. Liu, H. J. Zhao, Z. Y.
Tang, Nat. Energy, 2016, 1, 16184.

[13] W. Cheng, X. Zhao, H. Su, F. Tang, W. Che, H. Zhang, Q. Liu, Nat. Energy, 2019, 4, 115-122.

[14] M. Carraro, A. Sartorel, F. M. Toma, F Puntoriero, F. Scandola, S. Campagna, M. Prato, M. Bonchio, Top. Curr. Chem., 2011, 303, 121-150.

[15] Q. S. Yin, J. M. Tan, C. Besson, Y. V. Geletii, D. G. Musaev, A. E. Kuznetsov, Z. Luo, K. I. Hardcastle, C. L. Hill, Science, 2010, 328, 342-345.

[16] S. Tanaka, M. Annaka, K. Sakai, Chem. Commun., 2012, 48, 1653-1655.

[17] F. Song, Y. Ding, B. Ma, C. Wang, Q. Wang, X. Du, S. Fu, J. Song, Energy Environ. Sci., 2013, 6, 1170-1184.

[18] X.-B. Han, Z.-M. Zhang, Y.-G. Li, W. Lin, W.-S. You, Z.-M. Su, E.-B. Wang, J. Am. Chem. Soc., 2014, 136, 5359-5366.

[19] X.-B. Han, Y.-G. Li, Z.-M. Zhang, H.-Q. Tan, Y. Lu, E.-B. Wang, J. Am. Chem. Soc., 2015, 137, 5486-5493.

[20] L. Yu, X. Du, Y. Ding, H. Chen, P. Zhou, Chem. Commun., 2015, 51, 17443-17446.

[21] L. Yu, Y. Ding, M. Zheng, Appl. Catal. B-Environ., 2017, 209, 45-52.

[22] M. Zheng, Y. Ding, X. Cao, T. Tian, J. Lin, Appl. Catal. B-Environ., 2018, 237, 1091-1100.

[23] M. Blasco-Ahicart, J. Soriano-López, J. J. Carbó, J. M. Poblet, J. R. Galan-Mascaros, Nat. Chem., 2018, 10, 24-30.

[24] M. Martin-Sabi, J. Soriano-López, R. S. Winter, J.-J. Chen, L. Vilà-Nadal, D.-L. Long, J. R. Galán-Mascarós, L. Cronin, Nat. Catal., 2018, 1, 208-213.

[25] W. Luo, J. Hu, H. Diao, B. Schwarz, C. Streb, Y.-F. Song, Angew. Chem. Int. Ed., 2017, 56, 4941-4944.

[26] Q. Han, D. Sun, J. Zhao, X. Liang, Y. Ding, Chin. J. Catal., 2019, 40, 953-958.

\section{Graphical Abstract}

\section{Chin. J. Catal., 2020, 41: 853-857 doi: 10.1016/S1872-2067(20)63538-0}

\section{Fe-substituted cobalt-phosphate polyoxometalates as enhanced oxygen evolution catalysts in acidic media}

Xin-Bao Han, Dong-Xue Wang, Eduardo Gracia-Espino, Yu-Hui Luo, Yuan-Zhi Tan*, Dong-Fei Lu, Yang-Guang Li *, Thomas Wågberg *, En-Bo Wang, Lan-Sun Zheng Xiamen University, China;

Northeast Normal University, China;

Umeå University, Sweden;

Department of Chemical Engineering, Huaihai Institute of Technology, China

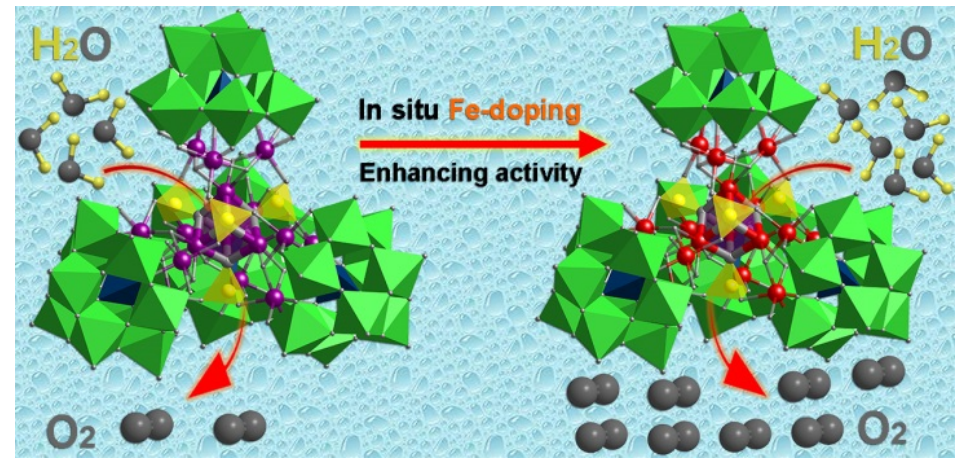

Fe-substituted cobalt-phosphate polyoxometalates with enhanced oxygen evolution activity and good stability in acidic media are reported, which are among the best non-noble metal-based acidic water oxidation catalysts that may serve as a molecular model of multimetallic hydr(oxy)oxides. 
[27] C. Shang, C. Cao, D. Yu, Y. Yan, Y. Lin, H. Li, T. Zheng, X. Yan, W. Yu, S. Zhou, J. Zeng, Adv. Mater., 2019, 31, 1805104.

[28] C. Lei, H. Chen, J. Cao, J. Yang, M. Qiu, Y. Xia, C. Yuan, B. Yang, Z. Li, X. Zhang, L. Lei, J. Abbott, Y. Zhong, X. Xia, G. Wu, Q. He, Y. Hou. Adv. Energy Mater., 2018, 8, 1801912.

[29] X.-B. Han, X.-Y. Tang, Y. Lin, E. Gracia-Espino, S.-G. Liu, H.-W. Liang, G.-Z. Hu, X.-J. Zhao, H.-G. Liao, Y.-Z. Tan, T. Wagberg, S.-Y. Xie, L.-S. Zheng, J. Am. Chem. Soc., 2019, 141, 232-239.

[30] L. Ruhlmann, C. Costa-Coquelard, J. Canny, R. Thouvenot, Eur. J. Inorg. Chem., 2007, 11, 1493-1500.

[31] M. Pope, Heteropoly and Isopoly Oxometalates, Springer, Berlin, 1983.

[32] I. C. Man, H.-Y. Su, F. Calle-Vallejo, H. A. Hansen, J. I. Martínez, N. G.
Inoglu, J. Kitchin, T. F. Jaramillo, J. K. Nørskov, J. Rossmeisl, ChemCatChem, 2011, 3, 1159-1165.

[33] E. M. Fernández, P. G. Moses, A. Toftelund, H. A. Hansen, J. I. Martínez, F. Abild-Pedersen, J. Kleis, B. Hinnemann, J. Rossmeisl, T. Bligaard, J. K. Nørskov, Angew. Chem. Int. Ed., 2008, 47, 4683-4686.

[34] J. S. Mondschein, J. F. Callejas, C. G. Read, J. Y. C. Chen, C. F. Holder, C. K. Badding, R. E. Schaak, Chem. Mater., 2017, 29, 950-957.

[35] A. Li, H. Ooka, N. Bonnet, T. Hayashi, Y. Sun, Q. Jiang, C. Li, H. Han, R. Nakamura, Angew. Chem. Int. Ed., 2019, 58, 5054-5058.

[36] R. Al-Oweini, A. Sartorel, B. S. Bassil, M. Natali, S. Berardi, F. Scandola, U. Kortz, M. Bonchio, Angew. Chem. Int. Ed., 2014, 53, 11182-11185.

\title{
铁取代的钴-磷多酸作为酸性介质中性能增强的析氧催化剂
}

\author{
韩新豹 ${ }^{\mathrm{a}}$, 王冬雪 ${ }^{\mathrm{a}}$, Eduardo Gracia-Espino ${ }^{\mathrm{c}}$, 骆昱晖, 谭元植, ${ }^{\mathrm{a},}$, 卢冬飞 ${ }^{\mathrm{a}}$, 李阳光, ${ }^{\mathrm{b}, \#}$, \\ Thomas Wågberg ${ }^{\mathrm{c}, \$}$, 王恩波 ${ }^{\mathrm{b}}$, 郑兰蒜 ${ }^{\mathrm{a}}$ \\ a厦门大学化学化工学院, 化学系, 固体表面物理化学国家重点实验室, 福建厦门361005, 中国 \\ ${ }^{\mathrm{b}}$ 东北师范大学化学学院多酸科学教育部重点实验室, 吉林长春130024, 中国 \\ c于默奥大学物理系, 于默奥90187, 瑞典 \\ d淮海工学院化学工程学院, 江苏连云港222000, 中国
}

摘要: 纯无机的非贵金属基双/三金属氢氧(氧)化物因其优异的析氧反应(OER)性能而得到广泛关注及研究. 但这些催化剂 的原子精度的结构表征较为困难, 阻碍了人们对其构效关系的认识, 从而影响了进一步对催化性能的精确调控. 金属有机 框架(MOFs)材料因具有明确的结构及化学组成可调等优点, 可以作为一类结构确定的OER电催化剂, 但是MOFs 为有机配 体和金属离子配位形成的框架材料, 与金属氢氧(氧)化物结构类型不同.

多酸是由高氧化态的 $\mathrm{Mo}^{\mathrm{VII}}, \mathrm{W}^{\mathrm{VII}}, \mathrm{V}^{\mathrm{VIV}}, \mathrm{Nb}^{\mathrm{V}}$ 和 $\mathrm{Ta} \mathrm{V}^{\mathrm{V}}$ 等组成的金属-氧簇. 多酸尺寸介于分子与块体氧化物之间, 可以被 看作一种具有明确结构的分子氧化物. 因此, 多酸可用作模型体系从分子水平上探究金属氢氧(氧)化物催化剂的反应机理. 此外, 多酸已被证明是很有前景的非贵金属水氧化催化剂.

对于OER, 酸性介质更具优势, 因为它与碱性介质相比具有高能效、低欧姆损耗、易于产物分离等优点. 但是, 非贵金 属OER电催化剂在酸性介质中很难稳定且性能通常不如贵金属催化剂. 制备酸性介质中高效和稳定的非贵金属OER电催 化剂仍然是一大挑战.

在本论文中, 我们首先采用 “原位同构取代” 策略, 将结构明确的 $\left[\left\{\mathrm{Co}_{4}(\mathrm{OH})_{3} \mathrm{PO}_{4}\right\}_{4}\left(\mathrm{SiW}_{9} \mathrm{O}_{34}\right)_{4}\right]^{32-}$ (1)钴-磷多酸阴离子中 的 Co原子替换成 $\mathrm{Fe}$ 原子, 合成了不同 $\mathrm{Fe}$ 含量的 $\left[\left\{\mathrm{Fe}_{2} \mathrm{Co}_{2}(\mathrm{OH})_{3} \mathrm{PO}_{4}\right\}_{4}\left(\mathrm{SiW}_{9} \mathrm{O}_{34}\right)_{4}\right]^{24-}$ (2)和 $\left[\left\{\mathrm{FeCO}_{3}(\mathrm{OH})_{3} \mathrm{PO}_{4}\right\}_{4}\left(\mathrm{SiW}_{9} \mathrm{O}_{34}\right)_{4}\right]^{28-}$ (3). 然后通过离子交换, 向 1,2 和 3 中引入 $\mathrm{Ba}^{2+}$, 成功合成了不溶于水的多酸阴离子结构维持的多相催化剂 $\mathrm{Ba}[\mathbf{1}], \mathrm{Ba}[2]$ 和 $\mathrm{Ba}[3]$. 性能最好的 $\mathrm{Ba}[3]$ 在 $0.5 \mathrm{~mol} \mathrm{~L}^{-1} \mathrm{H}_{2} \mathrm{SO}_{4}$ 溶液中达到 $10 \mathrm{~mA} \mathrm{~cm}{ }^{-2}$ 的电流密度仅需要 $385 \mathrm{mV}$ 过电位(无 $i R$ 校正), 比相同条件下无 $\mathrm{Fe}$ 取代的 $\mathrm{Ba}[1]$ 和商业 $\mathrm{IrO}_{2}$ 催化剂的过电位分别低 $66 \mathrm{mV}$ 和 $8 \mathrm{mV}$. 经过 2000 圈的循环伏安测试和 $24 \mathrm{~h}$ 的长时间电解测试, $\mathrm{Ba}[1], \mathrm{Ba}[2]$ 和 $\mathrm{Ba}[3]$ 均表现出较高的稳定性. 另外, 采用红外光谱(FT-IR)以及电感耦合等离子体质谱(ICP-MS)等多种表征 测试手段进一步确认了它们的稳定性.

本文采用的 “原位同构取代” 策略为合成更高效的结构明确的多金属催化剂提供了新思路, 同时也为进一步从分子水 平上探索相关催化机理提供了难得的模型.

关键词: 钴-磷; 多酸; 析氧反应; 同构取代

收稿日期: 2019-07-30. 接受日期: 2019-08-28. 出版日期: 2020-05-05.

*通讯联系人. 电话: 18559686980; 电子信箱: yuanzhi_tan@xmu.edu.cn

\#通讯联系人. 电子信箱: liyg658@nenu.edu.cn

\$通讯联系人. 电子信箱: thomas.wagberg@physics.umu.se

基金来源：国家自然科学基金(21771155, 21721001); 国家重点基础研究发展计划(2014CB845603, 2017YFA0204902); 国家重点 研发计划(2017YFA0204902); 瑞典Vetenskapsrådet (2017-04862); 瑞典能源署(Energimyndigheten, 45419-1).

本文的电子版全文由Elsevier出版社在ScienceDirect上出版(http://www.sciencedirect.com/science/journal/18722067). 